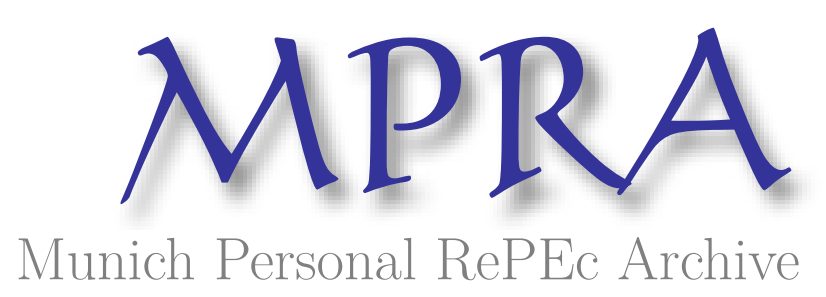

\title{
Job satisfaction in Italy: individual characteristics and social relations
}

Fiorillo, Damiano and Nappo, Nunzia

University of Napoli "Parthenope", University of Napolo "Federico II"

26 May 2011

Online at https://mpra.ub.uni-muenchen.de/31133/

MPRA Paper No. 31133, posted 26 May 2011 15:02 UTC 


\title{
Job satisfaction in Italy: individual characteristics and social relations
}

\author{
Damiano Fiorillo $^{1,2 \star}$ and Nunzia Nappo
}

May 2011

\begin{abstract}
This paper investigates the determinants of job satisfaction in Italy with particular emphasis on social relations. Our econometric analysis is based on four waves (1993, 1995, 1998 and 2000) of the Multipurpose Household Survey conducted annually by the Italian Central Statistics Office. The results of ordered probit regressions and robustness tests show that volunteering and meetings with friends are significantly and positively correlated with job satisfaction, with religious participation playing the biggest role. Our findings also show that meetings with friends increase job satisfaction through self-perceived health.
\end{abstract}

Keywords: Job satisfaction, social relations, social capital, health, statistical matching, Italy

JEL Classification: C31, J28, Z1

\footnotetext{
${ }^{1}$ Department of Economic Studies, University of Napoli Parthenope.

${ }^{2}$ Health, Econometrics and Data Group, University of York.

"Corresponding author: University of Napoli Parthenope, Department of Economic Studies "Salvatore Vinci", Via Medina 40, 80133 Napoli. Email: damiano.fiorillo@uniparthenope.it.

`University of Napoli Federico II, Department of Territorial and Environmental Analyses. Email: nunappo@unina.it.
} 


\section{Introduction}

The economics literature has recently shown great interest in social interactions and how they influence individual behavior. Amongst other things, social relations play a prominent role in jobmarket searches. A large and growing body of evidence emphasizes the positive role of friends and relatives (so-called social or informal networks) in helping people to find jobs (see Ioannides and Loury 2004; Bentolila et al. 2010; Pellizzari 2010; Ponzo and Scoppa 2010). Furthermore, happiness studies underline the importance of social interactions for individual well-being. Easterlin (1974) was one of the first economists to study statistics over time on the reported level of happiness. His seminal paper, entitled "Does economic growth improve the human lot? Some empirical evidence" (updated in 1995), opened up a contentious and continuing debate on the happiness-income paradox (Phelps 2001; Bruni and Porta 2006). The Easterlin paradox suggests that there is no link between a society's economic development and its average level of happiness. A recent explanation of the happiness-income paradox has been provided by the modern relational theory of happiness. It explains the Easterlin paradox, arguing that higher income levels are associated with a propensity to over-consume material goods and to underconsume relational interactions which are an important determinant of subjective life satisfaction (see Becchetti et al. 2008; Bruni and Stanca 2008; Becchetti et al. 2009).

In relatively recent times, economists used workers' reported job satisfaction to study the utility from work. According to Locke (1976), job satisfaction is an individual's subjective assessment of different aspects of his/her job whose analysis may provide a number of insights into certain aspects of the labour market. Workers' decisions about their labour force participation, whether to stay in a job or to quit, and how much effort to devote to their job are all likely to depend, in part, upon workers' subjective evaluation of their work, in other words, on their job satisfaction (Clark 1996). However, while Freeman $(1978,140)$ states "that subjective variables like job satisfaction ... contain useful information for predicting and understanding behaviour, but that they also lead to complexities due to their dependency on psychological states", Hamermesh (2001) says that "studying job satisfaction is still important for understanding labor-market behavior and perhaps economic activity more generally". The last statement explains why several studies have attempted to identify the determinants of job satisfaction (see Borjas 1979; Miller 1990; Meng 1990; Idson 1990; Clark 1996, 1997; Clark and Oswald 1996; Souza-Poza and Sousa-Poza 2000, 2003; Gazioglu and Tansel 2006; Jones and Sloane 2009). 
The present paper seeks to link the above research lines by analyzing the determinants of job satisfaction with particular emphasis on social interactions. Do social interactions at various levels - with friends, within the family, among volunteers in non-profit associations and by church attendance - influence job satisfaction? And if so, what are the possible causes?

The contribution of the paper to the literature is twofold. First, it complements the existing literature on job satisfaction by analyzing the potential relevance of social relations. Second, it extends the country evidence on the determinants of job satisfaction. To the best of our knowledge, there are no studies which consider social interactions as determinants of job satisfaction.

Our empirical analysis employs the Multipurpose Household Survey (hereafter indicated as MHS) conducted annually by the Italian Central Statistical Office. This large dataset is one of the best available to study job satisfaction in a cross-section framework as it investigates a wide range of social behaviours and perceptions through face-to-face interviews of a sample of 20,000 households, roughly corresponding to 60,000 individuals. However, MHS does not collect information on household income. In order to overcome this limitation, the paper merges MHS with the Bank of Italy's Survey on Household Income and Wealth (hereafter abbreviated as SHIW) for four waves (1993, 1995, 1998 and 2000), using a statistical matching method. The SHIW covers 8,000 households composed of approximately 20,000 individuals. Through the statistical matching procedure, household income of an individual from the SHIW is imputed to a similar individual from the MHS in a pooled cross-section sample comprising four waves (1993, 1995, 1998 and 2000) of the MHS. The final dataset contains 70,000 observations.

In the empirical analysis, the dependent variable is job satisfaction, measured through the question "How satisfied do you feel with your work?". Possible responses to the above question are: very satisfied; quite satisfied; not very satisfied; not at all satisfied. The dependent variable has not been dichotomized to keep as much information as possible. As regards independent variables, our econometric analysis focuses on various aspects of social relations, including the frequency of meetings with friends and visits to relatives, volunteering in non-profit associations and church attendance. In addition, a number of socio-demographic and economic characteristics are employed as control variables including imputed household income.

Ordered probit regressions and robustness tests show that social interactions matter. While visits to relatives are not statistically significant, volunteer work and the frequency of meetings with friends are significantly and positively correlated with job satisfaction, with church attendance having the biggest impact on job satisfaction. Our findings also show that meetings with friends increase job satisfaction through self-perceived health. 
At this stage, the analysis still has some limitations such as the possibility of reverse causality. However, as the effect of social relations on job satisfaction has received no attention, the findings in this study are a starting point for further research aimed at exploring the above matter.

The paper is related to two other strands of literature. First, it contributes to the growing economic literature on happiness (for latest reviews of this literature see Di Tella and MacCulloch, 2006; Frey and Stutzer, 2002; and Van Praag et al., 2003). Within this literature papers that use social interactions as determinants of life satisfaction are Bjørnskov (2006), Helliwell (2003, 2006, 2010), Becchetti et al. (2008), Bruni and Stanca (2008), Powdthavee (2008) and Becchetti et al. (2009). Second, the paper contributes to the literature on social capital (for an exhaustive survey see Durlauf and Fafchamps 2005). Meetings with friends and volunteering are forms of social capital in the sense of Putnam (1993). Unlike Bjørnskov (2006), our results point out the robustness of such forms of social capital.

The paper is organized as follows. Section 2 contains a short review of the relevant literature on the determinants of job satisfaction as well as suggestions regarding potential channels through which social interactions might influence job satisfaction. Section 3 describes the data and presents descriptive analysis. Section 4 illustrates the main results from our econometric analysis. The last section concludes.

\section{Job satisfaction and social relations}

This section provides a brief overview of previous studies on the determinants of job satisfaction. The channels through which social interactions might influence job satisfaction will be analyzed.

\subsection{Determinants of job satisfaction: an overview of the literature}

Economists, who tend to avoid data on subjective feelings (Freeman 1998; Sloane and Williams 2000), have long left the study of job satisfaction to other disciplines. However, investigating how people feel about their job provides useful information as regards some individual behaviours such as job quits (Hamermesh 1977; Freeman 1978; McEvoy and Cascio 1985; Akerlof et al.1988; Shields and Price 2002), absenteeism and productivity (Vroom 1964; Mangione and Quinn 1975; Clegg 1983). Furthermore, job satisfaction has been considered a component of the whole well-being of an individual (Clark and Oswald 1996). 
Both workers' personal characteristics (demographic variables such as age, gender, education, marital status), and characteristics of the job itself (such as hours of work, income, professional status, activity sector) are explanatory variables in the job satisfaction equation.

As regards gender, by and large, females experience significantly more job satisfaction than males (Clark 1997; Sloane and Williams 2000; van Praag et al. 2003; Gaziougly and Tansel 2006) $)^{1}$. Expectations play an important role in explaining the above result: "those who expect less from working will be more satisfied with any given job" (Clark 1996). Empirical evidence shows that within the labour market women hold poorer positions than men and therefore have lower expectations. However, gender-job satisfaction differences are expected to diminish when employment opportunities for women and men converge (Clark 1997; Sousa-Poza and SousaPoza 2003).

As concerns the relationship between job satisfaction and marital status, in some European countries $^{2}$ single people emerge among those most - if not the most - satisfied with their jobs (European Foundation for the Improvement of Living and Working Conditions, 2007). According to Clark $(1996,1997)$ marriage has a strong positive effect on women's job satisfaction.

The relationship between age and job satisfaction is also controversial: some studies show it is a U-shaped relationship (Clark 1996; Clark et al. 1996; Sloane and Ward 2001; Blanchflower and Oswald 2004; van Praag 2003; Ghinetti 2007). Others (Belcastro and Koeske 1996; Billingsley and Cross 1992; Cramer 1993; Jones Johnson and Johnson 2000; Larwood 1984; Loscocco 1990; Saal and Knight 1988) reach the conclusion that job satisfaction increases with age.

As regards education, by and large, it seems that job satisfaction depends on how much aspirations match with education. However, findings are controversial (Camp 1994; Loscocco 1990; Ting 1997; Vorster 1992). A well-established result is the negative relationship between education and job satisfaction (Clark 1996, 1997; Clark and Oswald 1996; Sloane and Williams 2000; Souza-Poza and Sousa-Poza 2003; Jones and Sloane 2009). By contrast, Battu et al. (1999), Jones Johnson and Johnson (2000), and Vila and García-Mora (2005) show a positive relationship between the two. Finally, Lambert et al. (2001) find no relationship.

Looking at the relationship between (self-perceived) health and job satisfaction, results (Clark 1996, 1997; Souza-Poza and Souza-Poza 2003; Vila and García-Mora 2005; Booth and van Ours 2008; Ghinetti 2007; Jones and Sloane 2009) show a strong positive correlation between the two.

\footnotetext{
${ }^{1}$ Results presented in Nguyen et al. (2003) do not suggest any difference in overall satisfaction nor in satisfaction with pay, fringe benefits, promotion prospects and job security by gender.

2 This is the case in Austria, Bulgaria, Germany and Portugal. The opposite happens in Italy, Denmark and the Netherlands.
} 
The relationship between income and job satisfaction can be distinguished into on-the-job earned income and household income. Since working income indicates how the worker is evaluated by the employer, the larger is labour income, the higher is job satisfaction (Clark 1996, 1997; Clark and Oswald 1996; Sloane and Williams 2000; Van Praag et al. 2003; Vila and García-Mora 2005; Gaziougly and Tansel 2006; Ghinetti 2007; Jones and Sloane 2009). As concerns household income, van Praag et al. (2003) and Pedersen and Schmidt (2008) found a positive relationship with job satisfaction as well as Booth and van Ours (2008) but only for men.

Working hours are also likely to influence job satisfaction. Findings are controversial since the variable "hours worked" may cause econometric problems in the job satisfaction equation: for some workers it is a choice variable and therefore may be endogenously determined. Negative effects of workings hours on job satisfaction have been widely reported (Clark 1996, 1997; Clark and Oswald 1996; Sloane and Williams 2000; van Praag et al. 2003; Souza-Poza and Souza-Poza 2003; Gaziouglu and Tansel 2006; Ghinetti 2007; and Jones and Sloane 2009). By contrast, Bartel (1981) and Schwochau (1987) found a positive relationship between the two.

Surveys on employees' opinions typically reveal that union members' reported job satisfaction is lower than that of non-members (Bryson et al. 2010). Empirical evidence regards mostly English-speaking countries. The negative effects of union membership on job satisfaction are documented by Freeman and Medoff (1984), Gordon and Denisi (1995) and Borjas (1979) for the US; Guest and Conway (2004), Bender and Sloane (1998) and Bryson et al. (2004) for the UK; Meng (1990) and Renaud (2002) for Canada; Miller (1990) for Australia; and Frenkel and Kuruvilla (1997) for South Korea.

Finally, job satisfaction may also be explained by the working status and activity sector. Previous results showed that managers and professionals are more satisfied with their jobs than clerical and sales staff (Clark 1996, 1997; Gaziouglu and Tansel 2006; Ghinetti 2007). Furthermore, as reported by Heywood et al. (2002) and Ghinetti (2007) the public sector increases overall job satisfaction.

\subsection{Social relations in job satisfaction: suggestions}

Over the past 15 years, economists have been studying the impact of relationships on the job on job satisfaction. Relations at work, both with colleagues and with management, seem to be an important explanatory variable in job satisfaction equations (Clark 1996, 1997; Souza-Poza and Sousa-Poza 2000). However, various aspects of the relational sphere of individuals have not been addressed. These aspects include relationships with family and friends as well as membership in 
various kinds of non-profit associations. This paper suggests that such types of social relations may have effects on job satisfaction through several channels.

First, social interactions facilitate the transmission of job information. Networks of relations are a place both to share previous and current work experience and to discuss important matters, such as security, pay and duties. This privileged channel of information lowers the costs of job information and speeds up the diffusion of knowledge on work aspects (economic, legal, technical), encouraging workers to adopt appropriate behaviour.

Second, social relations may favour mechanisms of mutual aid. In the event of employment loss, family, friends and religious associations may play a role in supporting workers through financial assistance, and may further help them to look for a new job (Granovetter 1973, 1983, 2005; Cattell 2001; Ioannides and Loury 2004). For example, members of religious communities may enjoy larger and more reliable informal networks from which to obtain economic support in times of adversity (Ellison 1991; Snoep 2008).

Third, social ties, including friendships and networks of relatives as well as active associational memberships, may foster the development of social norms, which, in turn, may support job-promoting behaviour such as that concerning safety and health. For example, religious communities may promote fundamental norms regarding health behaviour, business dealings and other dimensions of personal lifestyles (Levin and Vanderpool 1987) that may support occupational well-being.

Fourth, social relations provide moral and affective support which mitigates distress related to employment. This "buffering effect" may have a key role in reducing occupational stress as well as in modifying perceptions of distress associated with psychological suffering related to the job itself (Cummings 1990; Lu 1999). Workers who feel supported by others may feel less stressed. If you know your relatives, friends or religious associations will support you and there is someone with whom you can talk things through, stressful working situations may be more tolerable. For example, volunteering contributes to decrease psychological distress and buffers negative consequences of stressors (Rietschlin 1998). In addition, volunteering tends to decrease depression (Thoits and Hewitt 2001; Borgonovi 2008) and to increase self-esteem and selfconfidence (Harlow and Cantor 1996) with potential beneficial effects on job satisfaction. According to Soydemir et al. (2004), church attendance involves patterned engagements in ritual events to which participants assign special significance. Such ritualistic events may foster mental health, thus promoting feeling of (occupational) well-being. Furthermore, church attendance may improve (occupational) well-being by bolstering self-esteem and self-efficacy (Harlow Lim and Putnam 2010), as well as by moderating or mediating the harmful effects of stress (Ellison 1991). 
Fifth, social relations provide good opportunities for career prospectives. Meier and Stutzer (2008) underline two reasons for which voluntary work may be extrinsically rewarding, whereas behaviour motivated by extrinsic motivation "entails doing an activity because it leads to some outcome that is operationally separable from the activity itself. That is, extrinsic motivation concerns activities enacted because they are instrumental rather than because one finds the actions satisfying in their own right" (Deci et al., 2008, 12). Firstly, volunteering is likely to be undertaken as an investment in human capital. Individuals engage in volunteer activities to raise future earnings on the labour market. Secondly, people are likely to volunteer in order to invest in social networking. For example, employees may volunteer because they wish to signal their good traits and skills to employers that might be useful for their career prospects (Wilson 2000).

\section{Sample description and empirical strategy}

The data set used in the present study is drawn from MHS, a cross-sectional survey administered annually by ISTAT. The new MSH series was initiated in 1993. Every year a representative sample of 20,000 Italian households (roughly corresponding to 60,000 individuals) is surveyed on key aspects of daily life and behaviour. Though MSH is annual, it is not panel data. Among information provided, there are data on social relations; on a wide range of domain satisfactions as well as on socio-demographic characteristics.

However, MSH does not collect information on household income. To fill this gap, the ISTAT MSH was combined with the SHIW carried out by the Bank of Italy. The SHIW covers 8,000 households (20,000 individuals) and contains detailed information on income and wealth of family members as well as socio-demographic characteristics of the household. Both samples are representative of the Italian population at national and regional level. Basically, we imputed the household income of an individual from the SHIW to a similar individual from the MHS through a statistical matching procedure (see Appendix A for further details). After deleting observations with missing data on any of the variables used in analysis, the final dataset is a pooled cross section sample of 70,000 observations collected in the years 1993, 1995, 1998 and 2000.

The dependent variable is job satisfaction, measured through the question "How satisfied do you feel with your work?". Responses to the above questions are: "very satisfied"; "quite satisfied"; "not very satisfied"; "not at all satisfied". Answers were recoded on a scale from 1 to 4 , with 1 being "not at all satisfied" and 4 being "very satisfied".

Social relations are measured through the following set of variables: 
- The frequency of meetings with friends, coded as 1 if the interviewee meets friends every day or at least twice a week.

- The frequency of meetings with relatives, coded as 1 if the interviewee meets relatives every day or at least twice a week.

- Volunteering, coded as 1 if the individual did unpaid work for a volunteer association in the 12 months preceding the interview.

- Church attendance, measured by a binary variable which is equal to 1 if the interviewee goes to church or other places of worship one or more times a week.

Table 1 presents the weighted sample distribution of the dependent variable. The median value for job satisfaction is 3. Italian workers seem well satisfied with their job. The weighted trends of job satisfaction and social relations are shown in Table 2.

Although we focus chiefly on the role played by social relations, they are not the only determinants of job satisfaction. Indeed, MSH provides detailed information on demographic and social characteristics of all the individuals in a household. Many of these features have been found to be associated with job satisfaction. Such determinants include: age, gender, marital status, household size, presence and age of children, educational level, hours worked, health status, reading newspapers, homeownership, union, use of a bus to go to work, professional status and activity sector. These variables are used as control variables in the empirical investigation. Finally, we controlled for the natural logarithm of the imputed household income (sum of labour income, capital income and pensions) obtained through the statistical matching procedure. All the variables are described in detail in Table B1 in Appendix B. Summary weighted statistics are reported in Table 3. The correlation matrix between job satisfaction and social relational variables is reported in Table 4.

Table 3 shows that 73 percent and 34 percent of employees meet, respectively, friends and relatives one or more times per week; 9 percent of respondents supply unpaid labour for a volunteer association; 26 percent of the sample attends churches or other places of worship one or more times per week. Note that job satisfaction and these independent variables are positively and statistically correlated in Table 4.

Regarding other individual attributes, over half of the respondents are male and married. 41 percent of respondents have a high school education, while only 11 percent are educated beyond high school. The largest group of individuals (34\%) is aged between 31 and 40, followed by individuals aged from 41 to $50(25 \%)$. Over half of the sample comprises respondents with children aged between 0 and 
Table 1.Job satisfaction

\begin{tabular}{lcc}
\hline Satisfaction level & Number of individuals & Percentage \\
\hline 4 (Very satisfied) & 11262 & 16.04 \\
3 (Quite satisfied) & 43828 & 62.29 \\
2 (Not very satisfied) & 12144 & 17.64 \\
1 (Not at all satisfied) & 2766 & 4.03 \\
\hline
\end{tabular}

Table 2. Job satisfaction and social relation variables across time (average)

\begin{tabular}{lllll}
\hline & 1991 & 1993 & 1995 & 2000 \\
\hline Job satisfaction & 2.87 & 2.89 & 2.89 & 2.96 \\
Volunteering & 0.09 & 0.09 & 0.10 & 0.10 \\
Meetings with friends & 0.73 & 0.75 & 0.71 & 0.73 \\
Meetings with relatives & 0.33 & 0.33 & 0.35 & 0.33 \\
Church attendance & 0.29 & 0.26 & 0.24 & 0.24 \\
\hline
\end{tabular}

12 and work between 31 and 40 hours per week. Interestingly, 84 percent of respondents stated they were in good health; 69 percent are homeowners and 32 percent habitually read a newspaper.

The empirical strategy follows Blanchflower and Oswald (2004) and assumes that there exists a reported well-being function associated with job satisfaction $\mathrm{j}$ :

$$
r_{j}=h_{j}\left(u_{j}(s, y, z, t)\right)+e_{j}
$$

where $r$ denotes some self-reported number or level collected in the survey associated with job satisfaction $\mathrm{j}$. The $u(\ldots)$ function is the respondent's true well-being associated with job satisfaction $\mathrm{j}$ and it is observable only to the individual asked; $h(\ldots)$ is a non-differentiable function relating actual to reported well-being for job satisfaction $\mathrm{j}$; $s$ represents social relations; $y$ denotes income; $z$ is a set of socio-demographic and personal characteristics and $e$ is an error that subsumes the inability of human beings to communicate accurately their well-being levels associated with job satisfaction $\mathrm{j}$.

The empirical counterpart of Eq. (1) is

$$
J S_{i t}^{*}=\alpha+\beta S_{i t}+\lambda Y_{i t}+Z k_{i t}^{\prime} \delta+\varepsilon_{i t}
$$


Table 3. Descriptive statistics

\begin{tabular}{|c|c|c|c|}
\hline Variable & Mean & S.D. & Obs. \\
\hline Job satisfaction & 2.90 & 0.70 & 70000 \\
\hline Volunteering & 0.09 & 0.29 & 70000 \\
\hline Meetings with friends & 0.73 & 0.44 & 69839 \\
\hline Meetings with relatives & 0.34 & 0.47 & 70000 \\
\hline Church attendance & 0.26 & 0.44 & 69835 \\
\hline Male & 0.63 & 0.48 & 70000 \\
\hline Single, with partner & 0.01 & 0.10 & 70000 \\
\hline Married & 0.67 & 0.47 & 70000 \\
\hline Divorced & 0.05 & 0.22 & 70000 \\
\hline Widowed & 0.01 & 0.12 & 70000 \\
\hline Age 31-40 & 0.34 & 0.47 & 70000 \\
\hline Age41-50 & 0.25 & 0.43 & 70000 \\
\hline Age 51-60 & 0.13 & 0.34 & 70000 \\
\hline Age $>61$ & 0.02 & 0.16 & 70000 \\
\hline Household size & 3.24 & 1.20 & 70000 \\
\hline Children0_5 & 0.25 & 0.51 & 70000 \\
\hline Children6_12 & 0.28 & 0.56 & 70000 \\
\hline Children13_17 & 0.17 & 0.44 & 70000 \\
\hline Junior high school & 0.34 & 0.47 & 70000 \\
\hline High school (diploma) & 0.41 & 0.49 & 70000 \\
\hline Bachelor's degree & 0.11 & 0.32 & 70000 \\
\hline$<16$ hours pw & 0.03 & 0.18 & 69444 \\
\hline 17-30 hours pw & 0.11 & 0.31 & 69444 \\
\hline $31-40$ hours pw & 0.52 & 0.50 & 69444 \\
\hline Household income (ln) & 10.77 & 0.43 & 70000 \\
\hline Bad health & 0.03 & 0.18 & 69253 \\
\hline Good health & 0.84 & 0.37 & 69253 \\
\hline Newspapers & 0.32 & 0.47 & 69862 \\
\hline Homeowner & 0.69 & 0.46 & 70000 \\
\hline Union & 0.16 & 0.37 & 69938 \\
\hline Bus & 0.05 & 0.22 & 70000 \\
\hline Entrepreneur & 0.10 & 0.30 & 70000 \\
\hline Self-employed & 0.16 & 0.36 & 70000 \\
\hline Manager & 0.01 & 0.11 & 70000 \\
\hline Middle manager & 0.03 & 0.17 & 70000 \\
\hline Staff & 0.22 & 0.41 & 70000 \\
\hline Skilled worker & 0.21 & 0.41 & 70000 \\
\hline Apprentice & 0.01 & 0.08 & 70000 \\
\hline Agriculture & 0.04 & 0.19 & 70000 \\
\hline Manufacturing & 0.19 & 0.39 & 70000 \\
\hline Public Administration & 0.14 & 0.34 & 70000 \\
\hline Commerce & 0.11 & 0.32 & 70000 \\
\hline Finance & 0.03 & 0.17 & 70000 \\
\hline Transport & 0.03 & 0.17 & 70000 \\
\hline
\end{tabular}


Table 4. Correlation matrix: Job satisfaction and social relation variables

\begin{tabular}{|c|c|c|c|c|c|}
\hline & $\begin{array}{c}\text { Job } \\
\text { satisfaction }\end{array}$ & Volunteering & $\begin{array}{l}\text { Meetings with } \\
\text { friends }\end{array}$ & $\begin{array}{l}\text { Meetings with } \\
\text { relatives }\end{array}$ & $\begin{array}{c}\text { Church } \\
\text { attendance }\end{array}$ \\
\hline Job satisfaction & 1.00 & & & & \\
\hline Volunteering & $0.05^{* * *}$ & 1.00 & & & \\
\hline Meetings with friends & $0.04 * * *$ & $0.06^{* * *}$ & 1.00 & & \\
\hline Meetings with relatives & $0.01 * * *$ & 0.01 & 0.00 & 1.00 & \\
\hline Church attendance & $0.03 * * *$ & $0.12 * * *$ & -0.01 & -0.00 & 1.00 \\
\hline
\end{tabular}

Note: Asterisk $* * *$ denotes that the coefficient is statistically significant at the $1 \%$ level.

where job satisfaction (JS) is the reported well-being for individual $i$ at time $t ; S$ are vectors of social relations; $Y$ is the annual household income; vector $Z$ consists of the other variables that are supposed to influence occupational well-being, including age, gender, marital status, household size, presence and age of children, educational level, hours worked, health status, reading the newspaper, homeownership, union membership, taking bus to go to work, professional status and activity sector, as well as region and year dummies; and $\varepsilon$ is a random-error term.

We do not observe $J S^{*}$ in the data. Rather, we observe $J S$ as an ordinal variable, measured on a scale from 1 to 4 . Thus, the structure of Eq. (2) makes it suitable for estimation as an ordered probit model:

$$
P\left(J S_{i t}=J-1\right)=\Phi\left(\mu_{j}-\alpha-\beta S_{i t}-\lambda Y_{i t}-Z_{i t}^{\prime} \delta\right)-\Phi\left(\mu_{j-1}-\alpha-\beta S_{i t}-\lambda Y_{i t}-Z_{i t}^{\prime} \delta\right)
$$

where $\mathrm{J}$ takes a value from 1 to $4, \mu_{j}$ is defined as $J S=J-1$ when $\mu_{j-1}<J S^{*} \leq \mu_{j}$ and $\Phi($.$) is the$ cumulative normal distribution ${ }^{3}$.

\section{Econometric results}

In this section, we analyse the impact of individual and socio-economic features as well as social relations on job satisfaction. Section 4.1 shows results for baseline models.

\subsection{Baseline findings}

In Table 5, Columns (I) - (III) present the ordered probit estimations of Eq. (3), coefficients and standard errors, using job satisfaction as dependent variable. Marginal effects of the

\footnotetext{
${ }^{3}$ Following the existing literature, we interpret the reported level of job satisfaction as an ordinal measure, that is, higher levels reflect higher utility, but we do not assume that, for example, level 4 represents twice the utility of level 2.
} 
covariates of Column (III) of Table 5 express in terms of a change in the independent variables the probability of being not at all satisfied with one's job, not very satisfied, quite satisfied and very satisfied with one's job, as shown in Table 6.

Before discussing the results associated with the measurement of social relations, we consider findings regarding individual and socio-economic characteristics as control variables to compare them to those of previous studies using cross-sectional and longitudinal data.

\subsubsection{Individual and socio-economic characteristics}

In line with the literature (Clark 1997; Sloane and Williams 2000; van Praag et al. 2003; Graziougly and Tansel 2006), females are more satisfied with their job than males. The estimated coefficient of the male dummy variable is negative and statistically significant at a conventional level throughout (Table 5). Being male is associated with a 0.8 percent lower probability of declaring oneself very satisfied with one's job (Table 6).

The above result can be explained since the types of jobs that men and women do are different, as are their qualifications (Clark 1996; Gaziougly and Tansel 2006). Furthermore, for cultural reasons, women who are dissatisfied at work may find it easier than men to leave the labour force. Thus, satisfied women workers may be a statistical construct, since most of the women who would be dissatisfied at work do not work. Finally, men and women may answer job satisfaction questions in different ways: although the objective characteristics of the job may be the same, their expectations of what their job should be may well be different (Clark 1996). However, Clark (1997) claimed that gender differential cannot be explained by the different jobs that men and women do, or by sample selection. He found that for groups for which the gender differential in job expectations is less likely, the gender differential in job satisfaction disappears. He also found some evidence that women have lower expectations.

Italian married workers are more satisfied with their jobs than singles. The most occupationally satisfied are the widowed. Being married or widowed is associated respectively with a 1.8 and a 2.4 percent higher probability of declaring oneself very satisfied with one's work. Single people with partners and the divorced are more satisfied with their job than the reference group, though these results are not statistically significant. Overall, these results are in line with previous studies (e.g. Clark 1996, 1997).

In Table 5, we observe a statistically significant non-linear relationship between age dummies and job satisfaction. Non-linearity shows a U-shaped relationship, with those in the very young and old age groups being most satisfied. This result is in line with the literature (e.g. Clark 1996; 
Table 5. Job satisfaction equations. Ordered probit estimates.

\begin{tabular}{|c|c|c|c|c|c|c|}
\hline & \multicolumn{2}{|c|}{ I } & \multicolumn{2}{|c|}{ II } & \multicolumn{2}{|c|}{ III } \\
\hline & Coefficient & S. E. & Coefficient. & S. E. & Coefficient & S. E. \\
\hline Volunteering & $0.076 * * *$ & 0.012 & $0.071 * * *$ & 0.012 & $0.050 * * *$ & 0.011 \\
\hline Meetings with friends & & & $0.088 * * *$ & 0.014 & $0.088 * * *$ & 0.014 \\
\hline Meetings with relatives & & & & & 0.006 & 0.011 \\
\hline Church attendance & & & & & $0.111 * * *$ & 0.012 \\
\hline Male & $-0.042 * * *$ & 0.013 & $-0.047 * * *$ & 0.014 & $-0.033^{* *}$ & 0.014 \\
\hline Single, with partner & 0.019 & 0.048 & 0.031 & 0.049 & 0.044 & 0.048 \\
\hline Married & $0.068 * * *$ & 0.012 & $0.080 * * *$ & 0.013 & $0.078 * * *$ & 0.012 \\
\hline Divorced & -0.004 & 0.021 & 0.007 & 0.021 & 0.011 & 0.021 \\
\hline Widowed & $0.089 * * *$ & 0.034 & $0.104 * * *$ & 0.035 & $0.099 * * *$ & 0.036 \\
\hline Age $31-40$ & $-0.090 * * *$ & 0.009 & $-0.083^{* * *}$ & 0.009 & $-0.085^{* * *}$ & 0.009 \\
\hline Age41-50 & $-0.134 * * *$ & 0.012 & $-0.121 * * *$ & 0.012 & $-0.128 * * *$ & 0.011 \\
\hline Age 51-60 & $-0.139 * * *$ & 0.018 & $-0.122 * * *$ & 0.018 & $-0.138 * * *$ & 0.017 \\
\hline Age $>61$ & $-0.068^{*}$ & 0.039 & -0.051 & 0.038 & $-0.071^{*}$ & 0.037 \\
\hline Household size & $-0.039 * * *$ & 0.008 & $-0.039 * * *$ & 0.008 & $-0.040 * * *$ & 0.007 \\
\hline Children0_5 & 0.011 & 0.014 & 0.017 & 0.014 & 0.016 & 0.014 \\
\hline Children6_12 & -0.007 & 0.008 & -0.006 & 0.008 & -0.012 & 0.008 \\
\hline Children13_17 & $0.024 * *$ & 0.010 & $0.025 * *$ & 0.010 & $0.024 * *$ & 0.010 \\
\hline Junior high school & 0.025 & 0.023 & 0.026 & 0.023 & 0.025 & 0.022 \\
\hline High school (diploma) & 0.051 & 0.035 & 0.051 & 0.035 & 0.047 & 0.034 \\
\hline Bachelor's degree & $0.132 * * *$ & 0.047 & $0.132 * * *$ & 0.047 & $0.124 * * *$ & 0.046 \\
\hline$<16$ hours pw & -0.026 & 0.026 & -0.027 & 0.027 & -0.031 & 0.028 \\
\hline 17-30 hours pw & $-0.036^{*}$ & 0.020 & $-0.038^{*}$ & 0.021 & $-0.045^{* *}$ & 0.020 \\
\hline 31-40 hours pw & $-0.037^{*}$ & 0.019 & $-0.040 * *$ & 0.020 & $-0.042 * *$ & 0.019 \\
\hline Household income $(\ln )$ & $0.131 * * *$ & 0.031 & $0.132 * * *$ & 0.030 & $0.133 * * *$ & 0.030 \\
\hline Bad health & $-0.103 * * *$ & 0.026 & $-0.102 * * *$ & 0.026 & $-0.101 * * *$ & 0.025 \\
\hline Good health & $0.244 * * *$ & 0.010 & $0.241 * * *$ & 0.011 & $0.241 * * *$ & 0.011 \\
\hline Newspapers & $0.144 * * *$ & 0.010 & $0.141 * * *$ & 0.011 & $0.141 * * *$ & 0.011 \\
\hline Homeowner & $0.057 * * *$ & 0.013 & $0.055 * * *$ & 0.013 & $0.050 * * *$ & 0.012 \\
\hline Union member & $-0.049 * * *$ & 0.016 & $-0.051 * * *$ & 0.016 & $-0.049 * * *$ & 0.016 \\
\hline Bus & $-0.083^{* * *}$ & 0.019 & $-0.081 * * *$ & 0.019 & $-0.079 * * *$ & 0.019 \\
\hline Employer & $0.091 * * *$ & 0.019 & $0.089 * * *$ & 0.019 & $0.091 * * *$ & 0.019 \\
\hline Self-employed & 0.009 & 0.012 & 0.007 & 0.012 & 0.010 & 0.011 \\
\hline Manager & 0.017 & 0.037 & 0.019 & 0.038 & 0.016 & 0.037 \\
\hline Middle manager & 0.038 & 0.029 & 0.041 & 0.029 & 0.044 & 0.029 \\
\hline Staff & $-0.019 *$ & 0.011 & $-0.019 *$ & 0.011 & -0.019 & 0.011 \\
\hline Skilled worker & $-0.067 * * *$ & 0.011 & $-0.067 * * *$ & 0.011 & $-0.065^{* * *}$ & 0.011 \\
\hline Apprentice & -0.109 & 0.067 & -0.110 & 0.067 & $-0.110^{*}$ & 0.066 \\
\hline Agriculture & -0.003 & 0.022 & -0.004 & 0.022 & -0.007 & 0.022 \\
\hline Manufacturing & $0.028 *$ & 0.016 & $0.027^{*}$ & 0.019 & $0.028^{*}$ & 0.016 \\
\hline Public Administration & $0.051 * * *$ & 0.019 & $0.051 * * *$ & 0.019 & $0.049 * *$ & 0.019 \\
\hline Commerce & -0.021 & 0.020 & -0.021 & 0.020 & -0.020 & 0.021 \\
\hline Finance & 0.050 & 0.034 & 0.048 & 0.035 & 0.049 & 0.036 \\
\hline Transport & 0.037 & 0.028 & 0.037 & 0.028 & 0.039 & 0.029 \\
\hline Regional dummies & \multicolumn{2}{|c|}{ Yes } & \multicolumn{2}{|c|}{ Yes } & \multicolumn{2}{|c|}{ Yes } \\
\hline Year dummies & \multicolumn{2}{|c|}{ Yes } & \multicolumn{2}{|c|}{ Yes } & \multicolumn{2}{|c|}{ Yes } \\
\hline No. of observations & \multicolumn{2}{|c|}{68537} & \multicolumn{2}{|c|}{68416} & \multicolumn{2}{|c|}{68325} \\
\hline Pseudo R-squared & \multicolumn{2}{|c|}{0.024} & \multicolumn{2}{|c|}{0.025} & \multicolumn{2}{|c|}{0.026} \\
\hline Log-likelihood & \multicolumn{2}{|c|}{-68088.80} & \multicolumn{2}{|c|}{-67918.46} & \multicolumn{2}{|c|}{-67762.30} \\
\hline
\end{tabular}

Notes: The dependent variable Job satisfaction takes discrete values and is based on a recoded self-declared leisure satisfaction (1 not at all satisfied, 2 not very satisfied, 3 quite satisfied, 4 very satisfied). The model is estimated with an ordered probit. Regressors' legend: see appendix B. Regional and years dummies are omitted from the Table for reasons of space. The standard errors are corrected for heteroskedasticity and clustering of errors at the regional level. The estimated cut points are not reported. The symbols $* * *, * *, *$ denote that the coefficient is statistically different from zero at 1,5 and 10 percent, respectively. 
Table 6. Marginal effects of Model III.

\begin{tabular}{|c|c|c|c|c|}
\hline & Not at all satisfied & $\begin{array}{l}\text { Not very } \\
\text { satisfied }\end{array}$ & Quite satisfied & Very satisfied \\
\hline Volunteering & -0.003 & -0.010 & 0.002 & 0.012 \\
\hline Meetings with friends & -0.007 & -0.018 & 0.005 & 0.020 \\
\hline Visiting relatives & -0.000 & -0.001 & 0.000 & 0.001 \\
\hline Church attendance & -0.008 & -0.023 & 0.004 & 0.027 \\
\hline Male & 0.002 & 0.007 & -0.001 & -0.008 \\
\hline Single, with partner & -0.003 & -0.009 & 0.002 & 0.011 \\
\hline Married & -0.006 & -0.016 & 0.004 & 0.018 \\
\hline Divorced & -0.000 & -0.002 & 0.000 & 0.002 \\
\hline Widowed & -0.007 & -0.020 & 0.002 & 0.024 \\
\hline Age 31-40 & 0.007 & 0.018 & -0.004 & -0.020 \\
\hline Age41-50 & 0.010 & 0.027 & -0.008 & -0.029 \\
\hline Age 51-60 & 0.011 & 0.029 & -0.010 & -0.031 \\
\hline Age $>61$ & 0.006 & 0.015 & -0.004 & -0.016 \\
\hline Household size & 0.003 & 0.008 & -0.002 & -0.009 \\
\hline Children0_5 & -0.001 & -0.003 & 0.000 & 0.004 \\
\hline Children6_12 & -0.001 & 0.002 & -0.000 & -0.003 \\
\hline Children13_17 & -0.002 & -0.005 & 0.001 & 0.005 \\
\hline Junior high school & -0.002 & -0.005 & 0.001 & 0.006 \\
\hline High school (diploma) & -0.003 & -0.010 & 0.002 & 0.011 \\
\hline Bachelor's degree & -0.009 & -0.025 & 0.003 & 0.031 \\
\hline$<16$ hours pw & 0.002 & 0.006 & -0.002 & -0.007 \\
\hline 17-30 hours pw & 0.003 & 0.009 & -0.002 & -0.010 \\
\hline 31-40 hours pw & 0.003 & 0.009 & -0.002 & -0.010 \\
\hline Household income (ln) & -0.010 & -0.027 & 0.006 & 0.031 \\
\hline Bad health & 0.008 & 0.021 & -0.007 & -0.023 \\
\hline Good health & -0.021 & -0.051 & 0.020 & 0.052 \\
\hline Newspapers & -0.010 & -0.029 & 0.005 & 0.034 \\
\hline Homeowner & -0.004 & -0.010 & 0.003 & 0.012 \\
\hline Union participation & 0.004 & 0.010 & -0.003 & -0.011 \\
\hline Bus & 0.006 & 0.017 & -0.005 & -0.018 \\
\hline Employer & -0.006 & -0.018 & 0.003 & 0.022 \\
\hline Self-employed & -0.001 & 0.002 & 0.000 & 0.002 \\
\hline Manager & -0.001 & -0.003 & 0.000 & 0.004 \\
\hline Middle manager & -0.003 & -0.009 & 0.002 & 0.011 \\
\hline Staff & 0.001 & 0.004 & -0.001 & -0.004 \\
\hline Skilled worker & 0.005 & 0.014 & -0.003 & -0.015 \\
\hline Apprentice & 0.009 & 0.023 & -0.008 & -0.025 \\
\hline Agriculture & 0.000 & 0.001 & -0.000 & -0.002 \\
\hline Manufacturing & -0.002 & -0.006 & 0.001 & 0.006 \\
\hline Public Administration & -0.004 & -0.010 & 0.002 & 0.012 \\
\hline Commerce & 0.001 & 0.004 & -0.001 & -0.005 \\
\hline Finance & -0.003 & -0.010 & 0.001 & 0.012 \\
\hline Transport & -0.003 & -0.008 & 0.001 & 0.009 \\
\hline
\end{tabular}


Clark et al. 1996; Sloane and Ward 2001; Blanchflower and Oswald 2001; van Praag 2003; Ghinetti 2007). Being in the age class between 51 and 60 reduces the probability of stating one is very satisfied with one's job by 3.1 percent.

Young workers may feel satisfied with their jobs because they have little experience of the labour market against which to judge their own work. As they learn about the labour market with some years of experience, they are able to better judge their work conditions. With experience, satisfaction drops during middle age. The subsequent rise in satisfaction until the age of retirement may be due to the effect of reduced aspirations with age: older workers may realize that they face limited alternative choices. It may also be true that they may attach less importance to such ambitions (Gaziougly and Tansel 2006). Details of these arguments can be found in Clark (1996) and Clark et al. (1996).

Job satisfaction seems to depend on family characteristics. The larger the number of people living with workers, the less satisfied are the workers with their jobs. The household size variable shows a statistically significant negative sign at 1 percent. Furthermore, workers with children aged between 13 and 17 are happier than workers with no children. Previous empirical evidence seems to be conflicting. Booth and van Ours (2008) find that the presence of children is not a significant factor in job satisfaction. On the other hand, van Praag et al. (2003) show that job satisfaction is negatively affected by family size, while Pedersen and Schmidt (2008) report that having children under 12 increases satisfaction with the main activity.

Table 5 shows that bachelor's degree holders have higher levels of job satisfaction than individuals with lower education or none at all (reference group). Having a bachelor's degree is associated with a 3.1 percent higher probability of stating one is very satisfied with one's job (Table 6). Since we are controlling for household income and professional status, it is not surprising that junior high school and diploma variables are not statistically significant. Bettereducated workers have access to better job positions, such that education affects utility, indirectly raising productivity and career prospects (Bryson et al. 2004; Clark 1997; Clark and Oswald 1996). Association between higher levels of education and job satisfaction is found in one strand of the literature (Battu et al. 1999; Jones Johnson and Johnson, 2000; Vila and García-Mora 2005).

Job satisfaction increases in cases of self-perceived health. Workers who state they are in poor health are less satisfied than workers who claim to be in fair health, while workers in good health are more satisfied than those who state they enjoy fair health. Enjoying good health increases the probability of declaring oneself very satisfied with one's job by 5.2 percent. This result is in line with previous empirical investigations reported in Section 2. 
In line with van Praag et al. (2003), Pedersen and Schmidt (2008) and, partially, with Booth and van Ours (2008) household income increases job satisfaction. Following van Praag et al. (2003) larger household income might well give each working member of the family more margin to be selective as regards the type of work undertaken, there being the possibility to leave unsatisfactory jobs.

Working hours are found positively correlated with job satisfaction. People who work between 17 and 40 hours per week are less satisfied with their job than people who work more than 40 hours per week. This finding is in line with one strand of the literature (e.g. Bartel 1981; Schwochau 1987). A possible explanation for this result might be related to better-educated workers. As stated above, better-educated workers access better positions, which increase career prospects and earnings. Consequently, such workers might be more satisfied with their job and may choose to work longer hours. Hence, the positive association between working hours and job satisfaction should be interpreted with caution because of an endogeneity problem.

A negative correlation is found between union participation (defined as a dummy variable with a value of 1 if the worker participates in meetings or supplies unpaid activity for a union) and job satisfaction. This relationship seems in line with the literature indicated in Section 2. The result points out that workers who participate in union meetings or supply volunteer work for a union are less satisfied with their jobs. However, as the literature on union membership shows, there might be an issue of endogeneity since dissatisfied workers are more likely to join unions. Another possible explanation, highlighted recently also by Bryson et al. (2010), relies on the fact that unions, by providing workers with a voice, encourage them to stay in jobs they dislike and to try to change their work conditions.

Workers who own the property where they live have more job satisfaction than those who are not. Previous empirical studies found that renters are more satisfied at work than homeowners (e.g. Clark 1996, 1997; Souza-Poza and Souza-Poza 2003). Following Clark (1996), two explanations are possible. If ownership is seen as a proxy for social status, and thus for the individual's reference group, homeowners could make comparisons against a reference group with worse jobs, and hence report higher levels of job satisfaction. Furthermore, such findings could indicate that homeowners are not interested in geographic job mobility possibly because they do not want to leave satisfying jobs.

Workers who are daily newspaper readers are more satisfied with their jobs than those who are not. Reading newspapers every day raises the probability of declaring oneself very satisfied with one's job by 3.4 percent. Workers who take a bus to go to work every day or several times a week 
are less satisfied with their job than workers do not. Taking a bus decreases the probability of high job satisfaction by 1.8 percent.

Employers report higher job satisfaction (than other professional positions) while manual workers (skilled workers and apprentices) state they are less happy with their jobs. Being an employer raises the probability of being very satisfied with one's job by 2.2 percent while being a skilled worker decreases the same probability by 1.5 percent, as found by Miller (1990). Table 5 shows that managers' occupations do not significantly differ from the other professional positions (e.g. reference group). Both workers employed in manufacturing and in the public administration sectors are more satisfied with their work than those employed in other sectors. This result seems to support previous empirical findings (Heywood et al. 2002; Ghinetti 2007). Working in public administration is associated with a 1.2 percent higher probability of being very satisfied with one's work. A possible explanation for this finding comes from Ghinetti $(2007,381)$ according to whom "besides wages, public employees also receive a welfare premium in terms of better working conditions, especially higher perceived job stability and a better social climate".

Finally, our results show that Italy is characterized by considerable geographical differences: the North-East regions present a positive and highly significant correlation with job satisfaction, whereas satisfaction with work dramatically decreases in southern regions.

\subsubsection{Social relations}

In this section we focus on the relationship between social relations and job satisfaction. In Table 5, Column III first shows a positive relationship (statistically significant at $1 \%$ ) between volunteer work in activities of official volunteer service associations and job satisfaction. Volunteering is associated with a 1.2 percent higher probability of stating one is very satisfied with one's job. This could well be explained by the fact that volunteering is undertaken as a result of extrinsic motivation. Through voluntary work, social contacts evolve: this can help establish business contacts and might be useful for employees to signal their good traits and skills to employers with career prospects. Therefore, the correlation between volunteering and job satisfaction would be due to expectations of higher future earnings.

The impact of meeting friends on job satisfaction is positive and statistically significant at 1 percent as well. Meeting friends is associated with a 2.0 percent higher probability of high job satisfaction. This is likely to happen because these may be channels of employment information and mutual aid mechanisms. As we stated in section 2, relational networks with friends are a forum for sharing job information and to get economic support which could compensate levels of job stress. 
The effect of visiting relatives is positive but not statistically significant. In our analyses, reliance on the network of relatives is not associated to occupational well-being. A feasible reason for this finding recalls Granovetters' distinction between strong and weak ties. For workers' job satisfaction strong ties, such as relatives, are not central.

Finally, church attendance has a positive and statistically significant effect at 1 percent on job satisfaction. Church attendance is associated with a 2.7 percent increased probability of high job satisfaction. Religious participation might enhance individual job satisfaction in the following ways. First, religious associations can provide information and economic support in times of adversity. Second, religious associations can promote fundamental norms, such as those regarding health and other dimensions of workers' lives, which may positively influence job satisfaction.

\subsection{Robustness tests}

We tested the robustness of the main results on social relations using economic satisfaction as the dependent variable. The MHS also contains information on how individuals rate their economic satisfaction: "How satisfied do you feel with your economic situation?". Responses to the above question are: "very satisfied"; "quite satisfied"; "not very satisfied"; "not at all satisfied". As for job satisfaction, we recoded the answers on a scale from 1 to 4 , with 1 being "not at all satisfied" and 4 being "very satisfied". Despite the high correlation between job satisfaction and economic satisfaction (0.37), we suppose that occupational well-being is a key component of economic satisfaction, but obviously not the only one. We use economic satisfaction as a test of reliability for job satisfaction. All our main results on social relations continue to hold with economic satisfaction as dependent variable (see Table 7). One interesting difference is that the visit to relatives variable is now statistically significant. This result seems to indicate that relatives are more important in workers' lives as economic and financial support than for employment issues.

We also test for heterogeneity in social relation measurements by re-estimating results of Table 5 separately for men and women: results only for social relation variables are shown in Table 8. For men, all previous results on social relations continue to have a positive and significant effect. For women, meeting friends and church attendance retain a positive and statistically significant sign, while volunteering is not significant. This last result shows that voluntary work is not important as regards job satisfaction for women. 
In the literature on social capital, volunteering, meeting friends and visits to relatives are measures of social capital (Fiorillo 2008, 2009; Sabatini 2008, 2009). We further tested the sensitivity of the key results in Table 5 via additional measures of social capital. We used membership in associations, distinguishing between passive membership (if the individual participated in meetings of an association in the 12 months prior to the interview), and active membership (if the individual did unpaid work for an association in the 12 months prior to the interview). The associations we accounted for are ecological and cultural as well as political parties. We also used other activities implying a certain degree of relational engagement, such as the habit of talking about politics. These variables are described in Table B1 in appendix B. In Table 9, we introduce these three social capital variables to see whether or not they affect the size and significance of the social relation coefficients. Key results are that none of these types of social capital significantly alters the size or significance of the key social relation variables, which remain significant at 1 percent with coefficients similar to those reported in Table 5.

\subsection{Indirect effects through self-perceived health}

As we saw in Section 2, volunteering, meeting friends and churchgoing may compensate for the negative effects of psychological stress from work and may also provide the individual with a sense of self-esteem with positive effects on self-perceived health (Thoits and Hewitt 2001; Music and Wilson 2003; Ellison 1991, 1993; Lelkes 2007). Hence, as reported in this section, we tested the indirect effect of volunteering, meeting friends and church attendance on job satisfaction through the impact on self-perceived-health. In other words, if these social relations increase job satisfaction indirectly, increasing the level of self-perceived health, we should expect that the combined term, obtained by multiplying the social relation variable by the self-perceived health variable, has a statistically positive sign in the job satisfaction equation. This means the rejection of the null hypothesis that self-perceived health differential does not depend on social relations.

As poor health enters the job satisfaction equation with a negative and statistically significant sign (Table 5), we multiply this variable by the single social relations variables. In Table 10, we see that the null hypothesis is rejected only for the combined term between meetings with friends and bad health. The coefficient is positive and statistically significant at 5 percent (Model II). While bad health reduces by 4.0 percent the probability of high job satisfaction being reported, the combined term between meeting friends and bad health is associated with a 3.0 percent higher 
Table 7. Robustness test: economic satisfaction equations. Ordered probit estimates.

\begin{tabular}{|c|c|c|c|c|c|c|}
\hline & \multicolumn{2}{|c|}{ I } & \multicolumn{2}{|c|}{ II } & \multicolumn{2}{|c|}{ III } \\
\hline & Coefficient & S. E. & Coefficient. & S. E. & Coefficient & S. E. \\
\hline Volunteering & $0.072 * * *$ & 0.014 & $0.063^{* * *}$ & 0.014 & $0.039 * * *$ & 0.014 \\
\hline Meeting friends & & & $0.113 * * *$ & 0.013 & $0.112 * * *$ & 0.013 \\
\hline Visitingatikatsves & & & & & $0.016^{* *}$ & 0.007 \\
\hline Church attendance & & & & & $0.136 * * *$ & 0.013 \\
\hline $\begin{array}{l}\text { Individual and socio- } \\
\text { economic characteristics }\end{array}$ & \multicolumn{2}{|c|}{ Yes } & \multicolumn{2}{|c|}{ Yes } & \multicolumn{2}{|c|}{ Yes } \\
\hline Regional dummies & \multicolumn{2}{|c|}{ Yes } & \multicolumn{2}{|c|}{ Yes } & \multicolumn{2}{|c|}{ Yes } \\
\hline Year dummies & \multicolumn{2}{|c|}{ Yes } & \multicolumn{2}{|c|}{ Yes } & \multicolumn{2}{|c|}{ Yes } \\
\hline No. of observations & \multicolumn{2}{|c|}{68376} & \multicolumn{2}{|c|}{68257} & \multicolumn{2}{|c|}{68169} \\
\hline Pseudo R-squared & \multicolumn{2}{|c|}{0.046} & \multicolumn{2}{|c|}{0.047} & \multicolumn{2}{|c|}{0.049} \\
\hline Log-likelihood & \multicolumn{2}{|c|}{-64038.32} & \multicolumn{2}{|c|}{-63873.83} & \multicolumn{2}{|c|}{-63697.97} \\
\hline
\end{tabular}

Notes: The dependent variable economic satisfaction takes discrete values and is based on a recoded self-declared leisure satisfaction (1 not at all satisfied, 2 not very satisfied, 3 quite satisfied, 4 very satisfied). The model is estimated with an ordered probit. Regressors' legend: see Table 5 and appendix B. Regional and year dummies are omitted from the Table for reasons of space. The standard errors are corrected for heteroskedasticity and clustering of errors at the regional level. The estimated cut-off points are not reported. The symbols $* * *, * * *$ denote that the coefficient is statistically different from zero at the 1,5 and 10 percent level.

Table 8. Robustness test: job satisfaction equations by gender. Ordered probit estimates.

\begin{tabular}{|c|c|c|c|c|}
\hline & \multicolumn{2}{|c|}{ Men } & \multicolumn{2}{|c|}{ Women } \\
\hline & Coefficient & S. E. & Coefficient. & S. E. \\
\hline Volunteering & $0.067 * * *$ & 0.020 & 0.025 & 0.020 \\
\hline Meeting friends & $0.086 * * *$ & 0.016 & $0.095 * * *$ & 0.023 \\
\hline Visiting relatives & -0.003 & 0.011 & 0.023 & 0.017 \\
\hline Church attendance & $0.117 * * *$ & 0.013 & $0.095 * * *$ & 0.014 \\
\hline $\begin{array}{l}\text { Individual and socio-economic } \\
\text { characteristics }\end{array}$ & \multicolumn{2}{|c|}{ Yes } & \multicolumn{2}{|c|}{ Yes } \\
\hline Regional dummies & \multicolumn{2}{|c|}{ Yes } & \multicolumn{2}{|c|}{ Yes } \\
\hline Year dummies & \multicolumn{2}{|c|}{ Yes } & \multicolumn{2}{|c|}{ Yes } \\
\hline No. of observations & \multicolumn{2}{|c|}{43043} & \multicolumn{2}{|c|}{25282} \\
\hline Pseudo R-squared & \multicolumn{2}{|c|}{0.028} & \multicolumn{2}{|c|}{0.021} \\
\hline Log-likelihood & \multicolumn{2}{|c|}{-42712.17} & \multicolumn{2}{|c|}{-24991.12} \\
\hline
\end{tabular}

Notes: The dependent variable economic satisfaction takes discrete values and is based on a recoded self-declared leisure satisfaction (1 not at all satisfied, 2 not very satisfied, 3 quite satisfied, 4 very satisfied). The model is estimated with an ordered probit. Regressors' legend: see Table 5 and appendix B. Regional and year dummies are omitted from the Table for reasons of space. The standard errors are corrected for heteroskedasticity and clustering of errors at the regional level. The estimated cutoffpoints are not reported. The symbols $* * *, * * *$ denote that the coefficient is statistically different from zero at the 1,5 and 10 percent levels. 
Table 9. Robustness test: job satisfaction equations with further measures of social capital. Ordered probit estimates.

\begin{tabular}{|c|c|c|c|c|c|c|}
\hline & \multicolumn{2}{|c|}{ I } & \multicolumn{2}{|c|}{ II } & \multicolumn{2}{|c|}{ III } \\
\hline & Coefficient & S. E. & Coefficient. & S. E. & Coefficient & S. E. \\
\hline Volunteering & $0.051 * * *$ & 0.013 & $0.051 * * *$ & 0.015 & $0.052 * * *$ & 0.015 \\
\hline Meeting friends & $0.088 * * *$ & 0.013 & $0.087 * * *$ & 0.013 & $0.090 * * *$ & 0.013 \\
\hline Visiting relatives & 0.007 & 0.011 & 0.007 & 0.011 & 0.007 & 0.011 \\
\hline Church attendance & $0.112 * * *$ & 0.012 & $0.111 * * *$ & 0.012 & $0.111 * * *$ & 0.012 \\
\hline Passive membership & -0.005 & 0.016 & -0.005 & 0.016 & 0.000 & 0.017 \\
\hline Active membership & & & -0.004 & 0.019 & -0.002 & 0.019 \\
\hline Politics & & & & & $-0.008 * *$ & 0.003 \\
\hline $\begin{array}{l}\text { Individual and socio- } \\
\text { economic characteristics }\end{array}$ & \multicolumn{2}{|c|}{ Yes } & \multicolumn{2}{|c|}{ Yes } & \multicolumn{2}{|c|}{ Yes } \\
\hline Regional dummies & \multicolumn{2}{|c|}{ Yes } & \multicolumn{2}{|c|}{ Yes } & \multicolumn{2}{|c|}{ Yes } \\
\hline Year dummies & \multicolumn{2}{|c|}{ Yes } & \multicolumn{2}{|c|}{ Yes } & \multicolumn{2}{|c|}{ Yes } \\
\hline No. of observations & \multicolumn{2}{|c|}{68193} & \multicolumn{2}{|c|}{68166} & \multicolumn{2}{|c|}{68118} \\
\hline Pseudo R-squared & \multicolumn{2}{|c|}{0.026} & \multicolumn{2}{|c|}{0.026} & \multicolumn{2}{|c|}{0.026} \\
\hline Log-likelihood & \multicolumn{2}{|c|}{-67619.73} & \multicolumn{2}{|c|}{-67599.47} & \multicolumn{2}{|c|}{-67551.10} \\
\hline
\end{tabular}

\footnotetext{
Notes: The dependent variable economic satisfaction takes discrete values and is based on a recoded self-declared leisure satisfaction (1 not at all satisfied, 2 not very satisfied, 3 quite satisfied, 4 very satisfied). The model is estimated with an ordered probit. Regressors' legend: see Table 5 and appendix B. Regional and year dummies are omitted from the Table for reasons of space. The standard errors are corrected for heteroskedasticity and clustering of errors at the regional level. The estimated cut-off points are not reported. The symbols ***,**,* denote that the coefficient is statistically different from zero at the 1,5 and 10 percent levels.
}

Table 10. Job satisfaction equations with combined terms. Ordered probit estimates

\begin{tabular}{|c|c|c|c|c|c|c|}
\hline & \multicolumn{2}{|c|}{ I } & \multicolumn{2}{|c|}{ II } & \multicolumn{2}{|c|}{ III } \\
\hline & Coefficient & S. E. & Coefficient. & S. E. & Coefficient & S. E. \\
\hline Volunteering & $0.046 * * *$ & 0.012 & & & & \\
\hline $\begin{array}{l}\text { Volunteering * bad } \\
\text { health }\end{array}$ & 0.140 & 0.092 & & & & \\
\hline Meeting friends & & & $0.083 * * *$ & 0.014 & & \\
\hline $\begin{array}{l}\text { Meeting friends*bad } \\
\text { health }\end{array}$ & & & $0.121^{* *}$ & 0.061 & & \\
\hline Church attendance & & & & & $0.111 * * *$ & 0.012 \\
\hline $\begin{array}{l}\text { Church attendance*bad } \\
\text { health }\end{array}$ & & & & & 0.021 & 0.048 \\
\hline Bad health & $-0.116 * * *$ & 0.026 & $-0.185 * * *$ & 0.062 & $-0.107 * * *$ & 0.033 \\
\hline $\begin{array}{l}\text { Individual and socio- } \\
\text { economic characteristics }\end{array}$ & \multicolumn{2}{|c|}{ Yes } & \multicolumn{2}{|c|}{ Yes } & \multicolumn{2}{|c|}{ Yes } \\
\hline Regional dummies & \multicolumn{2}{|c|}{ Yes } & \multicolumn{2}{|c|}{ Yes } & \multicolumn{2}{|c|}{ Yes } \\
\hline Year dummies & \multicolumn{2}{|c|}{ Yes } & \multicolumn{2}{|c|}{ Yes } & \multicolumn{2}{|c|}{ Yes } \\
\hline No. of observations & \multicolumn{2}{|c|}{68325} & \multicolumn{2}{|c|}{68325} & \multicolumn{2}{|c|}{68325} \\
\hline Pseudo R-squared & \multicolumn{2}{|c|}{0.026} & \multicolumn{2}{|c|}{0.026} & \multicolumn{2}{|c|}{0.026} \\
\hline Log-likelihood & \multicolumn{2}{|c|}{-67760.73} & \multicolumn{2}{|c|}{-67759.58} & \multicolumn{2}{|c|}{-67762.23} \\
\hline
\end{tabular}

Notes: see note to Table 7. 
probability of stating high job satisfaction. Hence this result seems to support the "buffering effect" of the networks of friends (see Fiorillo and Sabatini 2011a,b).

\section{Conclusions}

The paper provided an empirical analysis of the socio-economic determinants of job satisfaction in Italy, focusing on the role of social relations. To the best of our knowledge, this is the first study in which social interactions were considered determinants of job satisfaction. Four different measures of social relations were used: volunteering in non-profit associations, meeting friends, visiting relatives and church attendance. Ordered probit relationships are estimated by relating job satisfaction to a variety of individual, socio-economic characteristics as well as social relation variables. We used four waves, 1993, 1995, 1998 and 2000, of the Multipurpose Household Survey conducted annually by the Italian Central Statistical Office for 70,000 observations.

The results show that our dependent variable is positively associated with volunteering and interactions with friends. The size of these positive relationships eases as volunteering and the frequency of meetings increases. Visits to relatives are not significantly correlated with job satisfaction while church attendance is a significant explanatory variable whose size seems to be comparatively important. Furthermore, we also find meetings with friends increasing job satisfaction through self-perceived health.

The other findings can be summarized as follows: men are less satisfied than women; married interviewees are more satisfied than singles; family size reduces job satisfaction which is Ushaped in relation to age; higher household income and good self-perceived health produce higher levels of job satisfaction; active and passive participation in union meetings reduces job satisfaction; employees who have the habit of reading a newspaper every day exhibit higher levels of job satisfaction; entrepreuners are more satisfied than those in other professional positions while skilled workers are less satisfied; working in public administration increases job satisfaction. Contrasting with the literature, we found that the better-educated are more satisfied than poorly educated workers; long working hours increase satisfaction, while employees who own the property where they live are more satisfied with their job than employees who do not.

At this stage, the analysis still has some limitations. The possibility of reverse causality between social relations and job satisfaction must be taken into account. Obviously, this limit might yield biased results. With data at hand we cannot exclude this issue. However, as the role 
of social relations in job satisfaction has received no attention, the findings in this paper may be considered a starting point for further research in this direction.

\section{References}

Akerlof G. A., Rose A. K., Yellen J. L., (1988), Job switching and job satisfaction in the U.S. labour market, Brookings Papers in Economic Activity, 2, 493-582.

Bank of Italy, Archivio storico dell'Indagine sui bilanci delle famiglie italiane, years 1993-2000, Roma.

Bartel A. P., (1981), Race differences in job satisfaction: an reappraisal, Journal of Human Resources, 16, 294-303.

Battu H., Belfield, C.R., Sloane P.J., (1999). Overeducation among graduates: a cohort view. Education Economics, 7, 21-39.

Becchetti L., Trovato G., Bedoya D. A. L., (2009). Income, relational goods and happiness, Applied Economics, 1-18.

Becchetti L., Pelloni A., Rossetti F., (2008). Relational goods, sociability, and happiness, Kyklos, 61, 343-363.

Belcastro, B. R., Koeske, G.F., (1996), Job satisfaction and intention to seek graduate education, Journal of Social Work Education, 32, 315-328.

Bentolila S., Michelacci C., Suarez J., (2010). Social contacts and occupational choice, Economica, 77, 20-45.

Bjørnskov C., (2006). The multiple facets of social capital, European Journal of Political Economy, 22, 22-40.

Billingsley, B.S., Cross, L.H. (1992). Predictors of commitment, job satisfaction, and intent to stay in teaching: A comparison of general and special educators, Journal of Special Education, 25 , 453-472.

Blanchflower D. G., Oswald A. J., (2004), Well-being over time in Britain and USA, Journal of Public Economics, 88, 1359-1386.

Booth A. L., van Ours J. C., (2008), Job satisfaction and family happiness:the part-time work puzzle, Economic Journal, 118, F77-F99.

Borgonovi F., (2008), Doing well by doing good. The relationship between formal volunteering and self-reported health and happiness, Social Science and Medicine, 66, 2321-2334.

Borjas G., (1979), Job satisfaction, wages and unions, Journal of Human Resources, 14, 21-40.

Bruni L., Stanca L., (2008). Watching alone: relational goods, television and happiness, Journal of Economic Behavior \& Organization, 506-528.

Bruni L, Porta P. L. (2006), Measuring well-being and societal progress, draft paper for discussion at the JRC/OECD Workshop Series, 19-21 June 2006, Milano.

Bryson A., Cappellari L., Lucifora C., (2010), Why so unhappy? The effects of unionization on job satisfaction, Oxford Bulletin of Economics and Statistics, 72, 357-380.

Bryson A., Cappellari L., Lucifora C., (2004), Does union membership really reduce job satisfaction?, British Journal of Industrial Relations, 72, 357-380. 
Camp, S.D. (1994). Assessing the effects of organisational commitment and job satisfaction on turnover: an event history approach, Prison Journal, 42, 439-459.

Cattell V., (2001), Poor people, poor places, and poor health: the mediating role of social networks and social capital, Social Science and Medicine, 52, 1501-1516.

Clark, A. E., (1997). Job satisfaction and gender: Why are women so happy at work?, Labour Economics, 4, 341-372,

Clark A. E., (1996), Job satisfaction in Britain, British Journal of Industrial Relations, 34, 189217.

Clark, A. E., Oswald, A. J. (1996). Satisfaction and comparison income, Journal of Public Economics, 61,359-81.

Clark, A. E., Oswald, A. J., Warr P., (1996), Is job satisfaction u-shaped in age?, Journal of Occupational and Organizational Psychology, 69, 57-81.

Clegg C. W., (1983), Psychology of employee lateness, absence and turnover: methodology, a critique and an empirical study, Journal of Applied Psychology, 68, 88-101.

Cramer, D. (1993). Tenure, commitment, and satisfaction of college graduates in an engineering firm. Journal of Social Psychology, 133,791-797.

Cummings R. C., (1990), Job stress and the buffering effect of supervisory support, Group and Organization Studies, 8, 92-104.

Di Tella R., MacCulloch R., (2006). Some uses of happiness data in economics, Journal of Economic Perspectives, 20, 25-46.

Durlauf S.N., Fafchamps M., (2005). Social capital, in P. Aghion e S.N. Durlauf (eds.), Handbook of Economic Growth, vol. 1B, Amsterdam, Elseiver North-Holland, 1639-1699.

Easterlin, R. A., (1974), Does Empirical Growth Improve the Human Lot? Some Empirical Evidence, in David P. A., Reder M. W., (eds.), Nations and Households in Economic.

Ellison G., (1993), Religious involvement and subjective well-being, Journal of Health and Social Behavior, 32, 80-99.

European Foundation for the Improvement of Living and Working Conditions, 2007, Measuring job satisfaction in surveys - Comparative analytical report - http://www.eurofound.europa.eu

Fiorillo D., Sabatini S., (2011b), Quality and quantity: the role of social interactions in individual health" Health, Econometrics and Data Group working paper 11/04, University of York.

Fiorillo D., Sabatini S., (2011a), An exploratory analysis of the relationship between social interactions, income and health in Italy, Economics Bulletin, 31, 1336-1352.

Fiorillo D., (2010), Voluntary work and domain satisfactions: evidence from Italy, Department of Economic Studies Discussion Paper 6.2010, University of Napoli Parthenope.

Fiorillo D., (2009), Capitale sociale "robusto": analisi macro, evidenza micro, (2009), Rivista di Politica Economica, 1, 149-178.

Fiorillo D., (2008), Le determinanti del capitale sociale in Italia, Rivista Italiana degli Economisti, $13,81-135$.

Freeman R.B., (1978), Job satisfaction as an economic variable, American Economic Review, 68, 135-141. 
Frey B., Stutzer A., (2005). Does the political process mitigate or accentuate individual biases due the mispredicting future utility? In: McCaffery E., Slemrod J. (eds.), Behavioral Public Finance, New York, Russell Sage Foundation.

Frenkel, S. Kuruvilla, S., (1997), Determinants of Member Satisfaction with Unions in South Korea, Paper provided by Aarhus School of Business - Department of Economics in its series Papers with number 97-14.

Gaziougly S., Tansel A., (2006), Job satisfaction in Britain: individual and job related factors, Applied Economics, 38, 1163-1171.

Ghinetti P., (2007), The public-private job satisfaction differential in Italy, Labour, 21, 361-388.

Gordon M.E., Denisi A. S., (1995), A re-examination of the relationship between union membership and job satisfaction, Industrial and Labour Relations Review, 48, 222-236.

Granovetter M., (2005), The impact of social structure on economic outcomes, Journal of Economic Perspectives, 19, 33-50.wsei

Granovetter M., (1973), The strength of weak ties, American Journal of Sociology, 78, 13601380.

Hamermesh D. S., (2001). The changing distribution of job satisfaction, Journal of Human Resources, 36, 1-30.

Hamermesh D. S., (1977), A note on income and substitution effects in Search unemployment, Economic Journal, 87(346), 312-314.

Helliwell J. F., (2006). Well-being, Social Capital, and public policy: what's new?, Economic Journal, 116, C34-C45.

Helliwell J. F., (2003). How's life? Combining individual and national variables to explain subjective well-being, Economic Modelling, 20, 331-360.

Helliwell J. F., Huang H., (2010). How's the job? Well-being and social capital in the workplace, Industrial and Labor Relations Review, 63, 205-227.

Heywood J. S., Siebert W. S., Wei X., (2002), Worker sorting and job satisfaction: the case of union and government jobs, Industrial and Labor Relations Review, 55, 595-609.

Idson T. L., (1990). Establishment size, job satisfaction and the structure of work, Applied Economics, 22, 1007-18.

Istituto Nazionale di Statistica (ISTAT), Indagine MULTISCOPO sulle famiglie, aspetti della vita quotidiana, years 1993-2001, Roma.

Ioannides M., Loury L., (2004). Job information networks, neighborhood effects, and inequality. Journal of Economic Literature, 42, 1056-1093.

Jones Johnson G., Johnson W.R. (2000). Perceived over qualification and dimensions of job satisfaction: a longitudinal analysis, Journal of Psychology, 34, 537-556.

Jones R.J., Sloane P., (2009). Regional differences in job satisfaction, Applied Economics, 41, 1019-1041.

Lambert, E.G., Hogan, N.L., Barton, A., \& Lubbock, S.M. (2001). The impact of job satisfaction on turnover intent; A test of a structural measurement model using a national sample of workers, Social Science Journal, 38 (2), 233-251. 
Larwood, L. (1984). Organizational behavior and management, Boston: Kent Publishing Company.

Lelkes O., (2007), Tasting freedom: happiness, religion and economic transition, Journal of Economic Behavior and Organization, 59, 173-194.

Levin J. S., Vanderpool H. Y., (1987), Is frequent religious attendance really conducive to better health? Toward an epidemiology of religion, Social Science and Medicine, 24, 589-600.

Locke E.A., (1976). The nature and causes of Job satisfaction. In Dunnette M. D. (eds.), Handbook of Industrial and Organizational Psychology, Chicago, Rand-McNally.

Loscocco, K.A. (1990). Reactions to blue-collar work: A comparison of women and men. Work \& Occupations, 17, 152-178.

Lu L., (1999), work motivation, job stress and employees' well-being, Journal of Applied Management Studies, 8, 61-72.

Mangione J. W., Quinn R. P., (1975), Job satisfaction, counter-productive behavior and drug use in work, Journal of Applied Psychology, 60, 114-116.

McEvoy G. M., Cascio W. F., (1985), Strategies for reducing employee turnover: a metaanalysis, Journal of Applied Psychology, 70, 342-345.

Miller P., (1990), Trade unions and job satisfaction, Australian Economic Papers, 29, 226-248.

Meng R., (1990). The relationship between unions and job satisfaction, Applied Economics, 22, $1635-48$.

Pedersen P. J., Schmidt T. D., (2010), Happiness in Europe. Cross-counrty differences in the determinants of satisfaction with main activity, Journal of Socio-Economics, doi:10.1016/j.socec.2010.10.004.

Pellizzari M., (2010). Do Friends and Relatives Really Help in Getting a Good Job? Industrial and Labor Relations Review, 63, 494-510.

Phelps C. D., (2001). A clue to the paradox of happiness, Journal of Economic Behavior \& Organization, 45, 293-300.

Ponzo M., Scoppa V., (2010). The use of informal networks in Italy: efficiency or favoritism?, Journal of Socio-Economics, 39, 89-99.

Powdthavee N., (2008). Putting a price tag on friends, relatives and neighbours: using surveys of life satisfaction to value social relationships, Journal of Socio-Economics, 37, 1459- 1480.

Putnam R. (with R. Leonardi and R. Nanetti) (1993). Making democracy work, Princeton NJ, Princeton University Press.

Rässler S., (2002), Statistical matching, New York, Springer.

Renaud, S. 2002, Rethinking the Union Membership/Job Satisfaction Relationship: Some Empirical Evidence in Canada, International Journal of Manpower, 23, 137-150.

Rietschlin J., (1998), Voluntary association membership and psychological distress, Journal of Health and Social Behavior, 39, 348-355.

Saal, F.E., \& Knight, P.A. (1988). Industrial/Organisational Psychology: Science \& Practice. Belmont: Wadsworth.

Sabatini F., (2009) "Social Capital as Social Networks: a New Framework for Measurement and an empirical analysis of its determinants and consequences" Journal of Socio-Economics, 38, 429-442. 
Sabatini F., (2008) "Social Capital and the Quality of Economic Development" Kyklos, 61, 466499.

Schwochau S., (1987), Union effects and job attitudes, Industrial and Labour Relations Review, 40, 209-224.

Shield M. A., Price S. W., (2002), Racial harassment, job satisfaction and intentions to quit: evidence from the British nursing profession, Economica, 60, 295-326.

Sloane P. J. , Ward M. E., (2001), Cohort effects and job satisfaction of academics, Applied Economics Letters, 8, 787 - 91.

Sloane P. J. , Williams H., (2000), Job satisfaction, comparison earnings and gender, Labour, 14, 473-501.

Sousa-Poza A., Sousa-Poza A.A., (2003). Gender difference in job satisfaction in Great Britain, 1991-2000, Permanent or Transitory?, Applied Economics Letters, 10, 691-94.

Sousa-Poza A., and Sousa-Poza A.A., (2000). Well-being at work: a cross national analysis of the levels and determinants of job satisfaction, Journal of Socio-Economics, 29, 517-38.

Steel R. P., Ovalle N. K., (1984), A review and meta-analysis of research on the relationship between behavioral intentions and employee turnover, Journal of Applied Psychology, 69, 673686.

Thoits P. A., Hewitt L. N., (2001), Volunteer work and well-being, Journal of Health and Social Behavior, 42, 115-131.

Ting, Y. (1997). Determinants of job satisfaction of federal government employees, Public Personnel Management, 26, 313-335.

Vila L. E., García-Mora B., (2005), Education and the determinants of job satisfaction, Education Economics, 4, 409-425.

Van Praag B. M. S., Frijters P., Ferrer-i-Carbonell A., (2003). The anatomy of subjective wellbeing, Journal of Economic Behavior \& Organization, 51, 29-49.

Vorster, M.E. (1992). 'n Ondersoek na die verband tussen rolkonflik, werkstevredenheid en organisasieverbondenheid by gegradueerde en nie- gegradueerde werkende vroue in 'n hoëtegnologie vervaardigings-organisasie. Unpublished master's thesis, University of the Orange Free State, Bloemfontein, Free State.

Wharton A., Baron J. N., (1991), Satisfaction?: the psychological impact of gender segregation on women at work, Sociological Quarterly, 32, 365-87.

Wilson J., (2000), Volunteering, American Sociological Review, 26, 215-240. 


\section{Appendix A}

As in Fiorillo (2008), let $A$ be the MSH dataset (the so-called "base file") collecting information on $X_{A}$ variables for each of $n_{A}$ records, and let $B$ be the SHIW dataset (the "supplemental file") comprising $X_{B}$ variables for each of $n_{B}$ records. Let $X=\left(X_{1}, \ldots, X_{P}\right)$ be the vector of variables measured in both the files, i.e. for each of the units $n_{A}$ and $n_{B}$ included in the two datasets. The remaining variables in each of the files will be referred to as $Y=\left(Y_{1}, \ldots, Y_{Q}\right)$ in file $A$ and as $Z=\left(Z_{1}, \ldots, Z_{R}\right)$ in file $B$. The statistical matching procedure is aimed at creating a file $C$ collecting all the variables $X, Y$, and $Z$ for each of $n_{A}$ records of the base file. For each unit in file $A$ we identify a similar unit in file $B$ as a function of the $X$ "common" variables. Then, we impute the household income variable collected in the supplemental file $B$ (the SHIW) to the matching records in the base file $A$, in order to obtain an original dataset $C$ including all the variables of interest for the analysis. The inherent assumption in this procedure is that the random vector $Y$ given $X$ is independent of the random vector $Z$ given $X$. The conditional independence assumption implies that $Y^{\prime}$ s relationship to $Z$ can be totally inferred from $Y$ 's relationship to $X$ and $Z$ 's relationship to $X$. Thus, the distributions of $X, Y$, and $Z$ of the new file $C$ must be identical to the distributions of $X, Y$, and $Z$ empirically observed in the original files $A$ and $B$. As a consequence, the best test to evaluate the quality of the statistical matching relies on the marginal distributions of the variables. As stated by Rässler (2002, 23), "A statistical match is said to be successful if the marginal and joint empirical distributions of $Z$ and $Y$ as they are observed in the donor samples are nearly the same in the statistically matched file".

The common variables $X=\left(X_{1}, \ldots, X_{P}\right)$ shared by the original datasets are identified according to the following criteria: 1) they must have been classified and measured in the same (or very similar) way in both of the surveys. 2) They must have been observed for all the individuals included in the samples. 3) They can be assumed as possible determinants of job satisfaction and social interaction in the base file. Based on hints from previous studies, we chose the following variables: gender, age, education, family size, number of children, region of residence, work status, sector of activity, and homeownership. Statistical matching was then performed through a regression imputation with random residuals. In particular, the regression parameters of $Z$ (i.e. the household income) on $X$ were estimated on the SHIW. A random residual was then added to the regression prediction to obtain the imputed value of $z$ for each $a=1, \ldots, n_{A}$ record in file $A$. Finally, the quality of the procedure was controlled by comparing, for each of the considered 
years, the conditional distribution of the household income given $X$ in the new and the original files. The marginal distributions are not found to be statistically different ${ }^{4}$.

\footnotetext{
${ }^{4}$ Distributions are available from the authors upon request.
} 


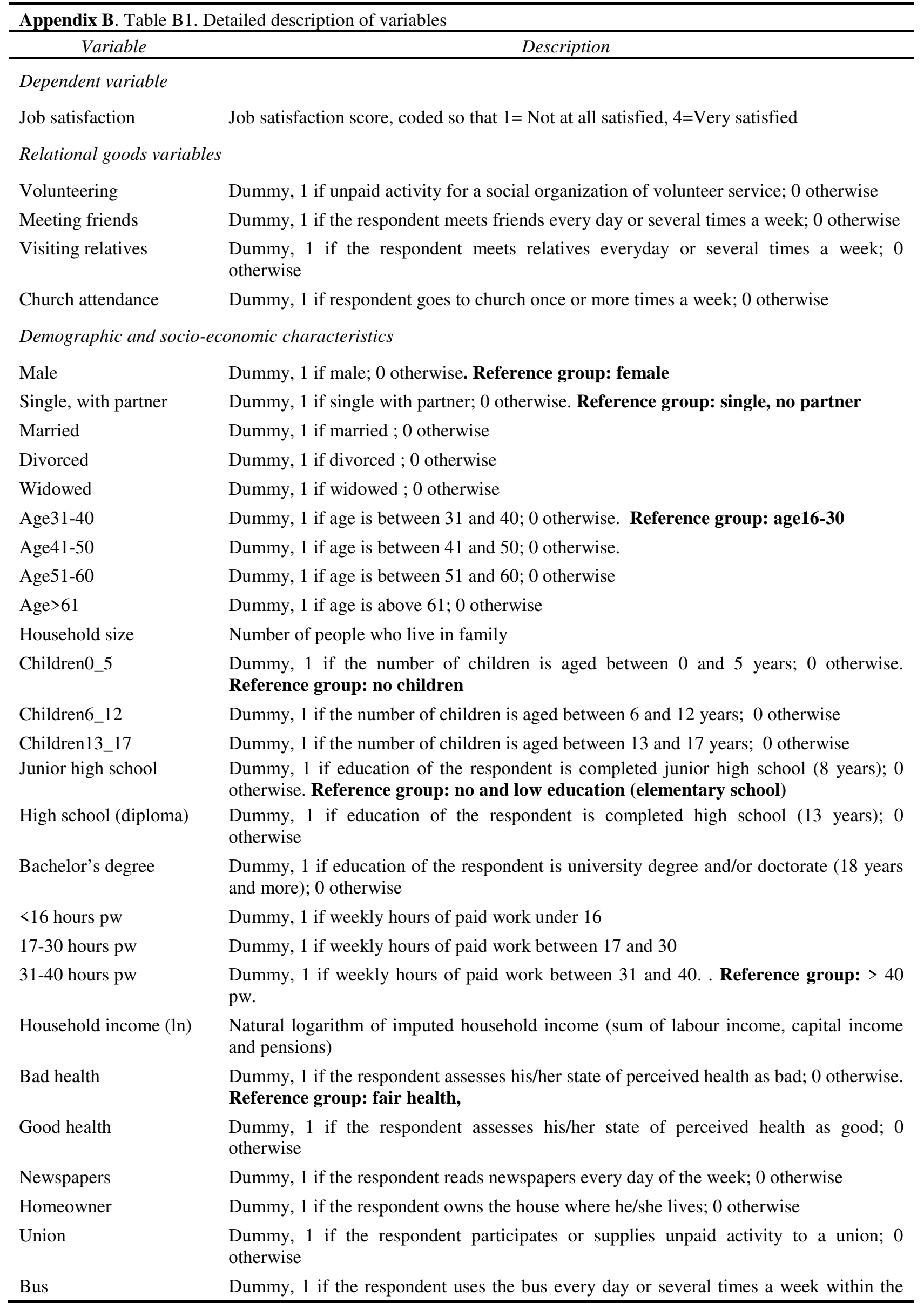


Employer

Self-employed

Manager

Middle manager

Staff

Skilled worker

Apprentice

Agriculture

Manufacturing

Public administration

Commerce

Finance

Transport

Passive membership

Active membership Politics
City for going to work; 0 otherwise

Dummy, 1 if the individual is employed as an entrepreneur; 0 otherwise Reference group: other professional positions.

Dummy, 1 if the respondent is self-employed; 0 otherwise.

Dummy, 1 if the respondent is employed as a manager; 0 otherwise

Dummy, 1 if the respondent is employed as a middle manager, 0 otherwise

Dummy, 1 if the respondent is employed as staff, 0 otherwise

Dummy, 1 if the respondent is employed as a skilled worker, 0 otherwise

Dummy, 1 if the respondent is employed as an apprentice, 0 otherwise

Dummy, 1 if individual is employed in the agriculture sector; 0 otherwise. Reference group: other sectors

Dummy, 1 if individual is employed in the manufacturing sector; 0 otherwise

Dummy, 1 if individual is employed in the public sector; 0 otherwise

Dummy, 1 if individual is employed in the business sector; 0 otherwise

Dummy, 1 if individual is employed in the finance sector; 0 otherwise

Dummy, 1 if individual is employed in the transport sector; 0 otherwise

Participation in meetings of formal associations, $1=$ ecological, cultural and political party

Unpaid activity for formal associations, 1 = other volunteer service and political party Dummy, 1 if individual talks politics every day or several times a week; 0 otherwise 
